\title{
FUNDAMENTAL LIBERTIES IN THE MALAYAN CONSTITUTION AND THE SEARCH FOR A BALANCE, 1956-1957
}

\author{
Joseph M. Fernando* \\ Department of History, Faculty of Arts and Social Sciences, \\ University of Malaya, Jalan Pantai Baharu, 50603 Kuala Lumpur, Malaysia \\ email: joefern7@gmail.com \\ Shanthiah Rajagopal ${ }^{* *}$ \\ Department of History, Faculty of Arts and Social Sciences, \\ University of Malaya, Jalan Pantai Baharu, 50603 Kuala Lumpur, Malaysia \\ email: victoria23_um@yahoo.com
}

Published online: 15 January 2017

To cite this article: Fernando, J. M. and Rajagopal, S. 2017. Fundamental liberties in the Malayan constitution and the search for a balance, 1956-1957. International Journal of Asia Pacific Studies 13 (1): 1-28, http://dx.doi.org/10.21315/ijaps2017.13.1.1

To link to this article: http://dx.doi.org/10.21315/ijaps2017.13.1.1

\begin{abstract}
This article examines the framing of the section on fundamental liberties in the 1957 Malayan constitution and analyses the underlying intentions and concerns of the framers and the various influences on the drafting process through an investigation of the primary constitutional documents. The section on fundamental liberties sought to provide for the growth of a democratic way of life in independent Malaya (now Malaysia). The Reid Commission, which framed the initial draft of the constitution, provided strong constitutional safeguards for basic fundamental liberties and rights such as personal liberty; equality of citizenship; freedom of movement, speech, assembly and association; freedom of religion and rights in respect of education and private property. Such provisions in most post-war Commonwealth constitutions drew little controversy. The complex multiracial and multireligious Malayan environment, however, required the framers to balance the competing demands of the various communities, on one hand, and the powers of the state over the citizens, on the other. Creating this balance proved challenging to the framers in attempting to provide for the basic
\end{abstract}


fundamental liberties found in most modern constitutions, while accommodating some local peculiarities.

Keywords: Fundamental liberties, Malayan constitution, fundamental rights, Malaysia constitution, Reid Commission

\section{INTRODUCTION}

Fundamental liberties or rights are an essential part of modern constitutions. They are primarily a distinct set of laws contained in a constitution intended to protect the basic civil, political and economic liberties of the citizens. The origins of fundamental liberties in most modern constitutions, however, are more recent. The insertion of a section on fundamental rights in constitutions was essentially a post-Second World War development. This was influenced by the process of decolonisation in Asia and Africa when new constitutions were drawn up for the emerging independent nation-states which felt the need for the affirmation of certain basic rights of the individual, and the codification in 1948 of the Universal Declaration of Human Rights by the United Nations. The fundamental rights in the American constitution and Ireland are an exception to this trend. In the United States, the Bill of Rights was added in 1791 during the ratification of the constitution by the states, having been rejected earlier by the Philadelphia constitutional convention in the summer of $1787 .{ }^{1}$ In Ireland, the constitution adopted in 1937 contained several articles (Articles 40-44) which provided protection for fundamental rights. ${ }^{2}$ Commonwealth constitutions in the colonial period did not often have a Bill of Rights or detailed provisions on fundamental liberties although protection for personal liberty, unlawful arrest and detention and safeguards for private property were commonly found in ordinary legislation. ${ }^{3}$ With decolonisation, many of the emerging nation-states decided that provisions protecting the fundamental rights were essential in their constitutions to safeguard the basic liberties of its citizens, including minority rights, from the excesses of governments. India, Pakistan, Ghana and Burma, for example, inserted sections on fundamental liberties in their constitutions.

The provisions on fundamental liberties in the Malayan constitution (Articles 5 to 13), is reflective of this growing post-war concern over basic civil and political safeguards in countries gaining independence and this influenced the constitution-making process considerably. The section on fundamental liberties in the 1957 Federation of Malaya (now Malaysia) constitution is wide-ranging. It contains detailed provisions on the rule of 
law and enforcement of the rule of law; personal liberty; protection against slavery and forced labour; equality of citizenship; freedom of movement, speech, assembly and association; freedom of religion and rights in respect of education and private property. ${ }^{4}$ These are not absolute rights and contain some restrictions as found in most modern constitutions. The complex multiethnic and multi-religious make-up of Malayan society, in addition to the on-going communist insurgency, required the framers to strike a balance between the communal interests and demands on one hand, and the powers of the state over its citizens, on the other. ${ }^{5}$ The Reid Commission, which prepared the draft Malayan constitution between 1956 and 1957, noted of "vague apprehensions" among sections of the society and concluded there was a need to affirm the basic rights in the constitution. While the Commission recognised that protection for basic fundamental rights were provided in the ordinary laws of the country, they nevertheless felt, after reading the numerous memoranda and listening to the oral submissions of organisations and individuals, that there was indeed a strong demand for guarantees on fundamental rights in the constitution. ${ }^{6}$ They recognised that almost all the newly independent nations in the Commonwealth had special provisions guaranteeing fundamental rights in their constitutions. Thus they included a wide-ranging section on fundamental liberties in the draft constitution.

Very little research has been conducted on the drafting of the section on fundamental liberties in the Malayan constitution and the intent of the framers. Much of the work on fundamental liberties in the Malayan (now Malaysian) constitution has been done in the field of legal studies. These include the works of R. H. Hickling, L. A. Sheridan, Mohamed Suffian Hashim, F. A. Trindade and H. P. Lee, Abdul Aziz Bari, Shad S. Faruqi and Andrew Harding. ${ }^{7}$ These works while useful in understanding the practical application of these constitutional provisions leave a gap in our understanding of the historical process of the framing of these provisions and the contentious nature of the crafting of these provisions. This article seeks to fill the gap in the existing literature by examining the framing of the section on fundamental liberties to discern the underlying intentions of the framers and the various influences on the drafting process. By tracing the historical process of the framing of the section, we can understand better the framers' concerns and the effort to achieve a fair balance between the varied demands in the polity.

Before we examine the framing of the section on fundamental liberties some background to the appointment of the constitutional commission and the constitution-making process would be useful. The demand for a constitutional commission to frame a new constitution 
originated from the Alliance party, the leading nationalist movement, during its campaign for the introduction of federal elections between 1953 and 1954. Following the Alliance's victory in the first federal election in July 1955, its leader Tunku Abdul Rahman urged the visiting Secretary of State for the Colonies, Alan Lennox-Boyd, to hold talks on Malayan independence and the appointment of a constitutional commission to draft a new constitution. ${ }^{8}$ As a result, a conference was held in London in January 1956 between the British government, the Alliance Party and representatives of the nine Malay Rulers. The London Conference agreed to the formation of a commission of legal experts from the Commonwealth to draft a new Malayan constitution while also agreeing to grant independence on 31 August 1957. ${ }^{9}$ Lord Reid, ${ }^{10}$ a Lord of Appeal in the Ordinary in the House of Lords, was selected to head the constitutional commission. The other members of the commission were the academic Sir Ivor Jennings, Master of Trinity Hall, Cambridge; Sir William McKell, a former governorgeneral from Australia; Justice B. Malik, chief justice of the Allahabad High Court in India; and Justice Abdul Hamid from the West Pakistan High Court. ${ }^{11}$ The commission started its work in late June 1956 and submitted the draft constitution on 21 February $1956 .{ }^{12}$ The commission received 131 memoranda from a wide range of political and socio-economic organisations and held more than 100 hearings throughout Malaya between June and November 1956. The draft constitution was reviewed by a Working Party in Kuala Lumpur comprising the British High Commissioner, the representatives of the Alliance party and the nine Malay rulers between February and April 1957. The revised constitution was then debated in the British parliament and the Federal Legislative Council in Malaya and came into force on 31 August 1957 when Malaya became independent.

\section{ORIGINS OF THE SECTION ON FUNDAMENTAL LIBERTIES}

The Reid Commission's terms of reference were broad and there was no specific instruction requiring provisions on fundamental liberties. The Commission was to make recommendations for a federal form of constitution for the whole country based on parliamentary democracy with a bicameral legislature. ${ }^{13}$ They were to provide for the establishment of a strong central government with a measure of autonomy for the states; safeguard the position of Their Highnesses as constitutional rulers; provide for the appointment of a Yang di-Pertuan Agong; include provision for a common nationality; and safeguard the special position of the Malays and 
the legitimate interests of other communities. ${ }^{14}$ In explaining the provisions for fundamental rights, the Reid Commission noted that the constitution should "define and guarantee certain fundamental rights." ${ }^{15}$ The Commission felt that while these rights were already established throughout Malaya, they found "in certain quarters vague apprehensions about the future." Subject to limited exceptions in conditions of emergency, they argued, there could be no objections to guaranteeing these rights. ${ }^{16}$

The insertion of a section on fundamental liberties in the draft of Malayan constitution by the Reid Commission was contentious. Initially, the leading members of the ruling Alliance party, the United Malays National Organisation (UMNO) and the Malayan Chinese Association (MCA), did not think there was a real need for an exclusive section in the constitution to guarantee fundamental liberties. They felt that the existing ordinary legislation provided adequate safeguards to protect the civil and political liberties of the individual. The junior partner in the Alliance, the Malayan Indian Congress (MIC), however, argued that a special section guaranteeing the fundamental rights of individuals should be included in the constitution. The MIC representatives involved in the Alliance intra-party talks and in the hearing with Reid Commission were lawyers who were obviously familiar with the elaborate provisions in the Indian constitution on fundamental rights. The MIC persuaded its partners, UMNO and MCA, that a section on fundamental liberties was essential. Thus the Alliance party's memorandum to the Reid Commission listed a long list of fundamental rights they felt could be included in the constitution to protect the basic rights of the citizens. Page 10 of the Alliance memorandum stated the constitution should guarantee the fundamental rights normally enjoyed by free peoples such as freedom of speech and expression; freedom of assembly; freedom of worship; freedom from want and freedom from fear. ${ }^{17}$ The Alliance provided a longer list of fundamental rights they felt should be written in the constitution in the appendix to their memorandum. ${ }^{18}$ Most of the fundamental rights stated in the longer list in the appendix were based on similar provisions in the Indian constitution. The evidence given during the oral hearing before the Commission indicates that the list was prepared by the MIC representatives in the Alliance committee. ${ }^{19}$ The Alliance leaders, however, had not thought out deeply the wording of the provisions for such a section and the memorandum to the Commission was relatively wide, loosely worded and included some vague requests for inclusion of provisions such as "freedom from want" and "freedom from fear." These were essentially principles enshrined in the 1948 Universal Declaration of Human Rights which were not legally enforceable. The Reid Commission, too, initially, did not give much attention to the section on fundamental 
liberties. The section is listed as the third last item on the list of subjects shortlisted for discussion and potential inclusion in the draft constitution. ${ }^{20}$ This is not surprising as the Commission was preoccupied with resolving the highly contentious inter-communal political issues such as citizenship, language, Malay special rights and the division of legal and financial powers between the federal government and the states. ${ }^{21}$

The first discussion of "fundamental rights" in the Commission is at the 34th meeting on 26 September 1956, almost four months after the panel began its work. The Commission was perplexed by the Alliance's long list of requests on fundamental liberties in its memorandum and wondered if all of it was necessary. During an internal discussion in the Commission, Lord Reid remarked: "The Alliance should be asked if all of these were really necessary." 22

The Commission noted that some of the demands on fundamental liberties made in the Alliance memorandum (such as "freedom from fear" and "freedom from want") were not enforceable by law and thus untenable. Nevertheless as the Commission listened to submissions from a range of organisations and individuals who expressed concerns over constitutional protection for basic liberties such as freedom of religion, education and language, they realised there was a need for a distinct section in the constitution to safeguard the basic civil and political liberties and began to give it more serious attention. A significant number of social and political organisations, 31 in total, had made representations on civil and political rights in their memoranda sent to the Reid Commission and in their oral testimonies. ${ }^{23}$ Their submissions emphasised the need for clear safeguards in the new constitution for freedom of worship, continued use of vernacular languages, rights in terms of education and equality of citizenship.

The People's Progressive Party, for example, noted in its memorandum that fundamental rights were the "most important part of the constitution" and that the Commission should adapt suitable parts from the Indian and Pakistan constitutions into the Malayan constitution. ${ }^{24}$ The PanMalayan Federation of Chinese Associations urged constitutional safeguards to protect the Chinese language and culture. ${ }^{25}$ The Labour Party regarded fundamental rights as a central issue and recommended that all Malayan nationals "should enjoy equal rights and share equal responsibilities."26 The Straits Chinese British Association of Penang in its memorandum stressed the importance of safeguards for fundamental liberties: "At no time in our history do we appreciate the value, the need of the importance of a guarantee for our fundamental liberties and rights and safeguards for minorities not only in reference to legislation but also in the field of executive action." 27 The Eurasian Union of Malaya wanted safeguards for 
freedom of worship and the "doctrine of religious liberty" to be written into the constitution. ${ }^{28}$ The Malayan Christian Council expressed the need to safeguard the fundamental liberties and emphasised the need to ensure "full religious freedom" was provided in the constitution. ${ }^{29}$ The Malayan Sikhs' Union urged constitutional safeguards for the Punjabi schools and language. ${ }^{30}$ The Persatuan Melayu Semenanjong based in Johore Bahru urged that all citizens should be "equal before the national law" and all citizens should be guaranteed freedom of religious worship. ${ }^{31}$ An Indian organisation based in Kuala Lumpur, the Malaya Tamil Pannai urged provisions in the constitution for "freedom of worship, freedom to learn the mother-tongue, and inalienable right to preserve their culture, customs and traditions." 32

The Commission gave priority to the submissions of the multicommunal Alliance Party as it was seen to represent the views the majority of the population. The exchanges at the hearing given to the Alliance Party by the Commission in this context are revealing. At the hearing, Lord Reid pointed out to the Alliance leaders that two types of fundamental freedoms had been included in the Alliance memorandum. One which was enforceable by the courts, and the other that could not and could cause political difficulties: ${ }^{33}$

There are two kinds of Fundamental Rights - those that are enforceable by the Court, as set out in page 10 [Alliance memorandum], and those which are extremely varied and cannot be enforceable by any Court, but merely guides the future political parties as to what they should do. Now, you put in here quite a lot of the second class of Fundamental Rights which you really cannot guarantee. I am wondering whether you want them to be put in such great detail or not all? $?^{34}$

Put in an awkward position, the leader of the Alliance delegation, Chief Minister Tunku Abdul Rahman, felt most of "five freedoms" suggested in the memorandum could be omitted: "All these can be taken out. The main thing is the Fundamental Rights. It was a suggestion from the Malayan Indian Congress (MIC), and that was why it was put in." ${ }^{35}$ The MIC representative, lawyer K. Ramanathan, interjected to persuade the Commission that legally enforceable rights should be included: "Whatever is not constitutionally enforceable, they could probably be taken out. Whatever rights should be protected by the Court would appear in the Constitution." ${ }^{36}$ Reid noted that any matters that should be addressed by the courts should be made sufficiently definite for the courts to enforce, 
remarking acerbically: "As regards to 'Freedom from Fear,' I very much fear that no Court or Government could do that." ${ }^{37}$

The Alliance's deputy head, Dato' Abdul Razak Hussein agreed with Reid, pointing out that the list in the appendix of the Alliance's memorandum was more detailed and legally enforceable. When another Commission member, Sir Ivor Jennings, asked if the Alliance wanted all the clauses listed in the appendix to be included, Tunku became a little defensive, reiterating that it was inserted at request of the MIC: "It was really put in on the suggestion of the Indian community as represented by the MIC. As far as UMNO and MCA are concerned, it is immaterial whether it is in or not - if we have to mention other rights, then there are millions of rights." ${ }^{38}$ Ramanathan then intervened again to stress that most of the provisions in the Alliance memorandum were legally enforceable: "1, 2 , and 3 could probably stand - they are enforceable by the court — and add to it the Appendix." ${ }^{39}$ Tunku added: "We have suggested five Fundamental rights which are recognised by all countries in the world-(1) Freedom of Speech and Expression; (2) Freedom of Assembly; (3) Freedom of Worship; (4) Freedom from Want; and (5) Freedom from Fear. I think under all these heads you can put in anything you like. ${ }^{40}$ Lord Reid then agreed that the Alliance's suggestions on fundamental liberties in the memorandum "could be put into a form." 41

The Alliance leaders left it essentially to the wisdom of the Commission to formulate a section on fundamental liberties. ${ }^{42}$ The discussion of fundamental liberties in the Malayan constitution during the Alliance's meeting with the Commission thus had an inauspicious start, and barely covers a page of the official record of the hearing given to the Alliance. The Alliance leaders had not thought out clearly the need and importance for such provisions in the constitution and were found a little wanting when questioned by the Commission. It was particularly Ramanathan's intervention and insistence during the hearing that persuaded Lord Reid and his panel. Nonetheless the draft of the section on fundamental liberties prepared by the Commission was commendable and legally sound. It was carefully drafted, wide-ranging and incorporated most of the basic fundamental rights found in Commonwealth constitutions. The framers of the 1957 Malayan constitution drew considerably from Common Law based Commonwealth constitutions and case precedents in India, Pakistan, Burma, Eire and Canada. ${ }^{43}$ Some provisions also drew from the constitutions of the United States, Ceylon and South Africa.

Jennings, a constitutional expert from Cambridge University, prepared the main working drafts for the section on fundamental liberties. The Commission members then reviewed the drafts and these were then 
revised and re-drafted several times before the final draft of Articles 5 to 13 were agreed upon. ${ }^{44}$ The final draft produced by the Reid Commission contained ten articles under the section called "Fundamental Liberties." These articles provided for the protection of most basic fundamental rights. Article 3 and Article 4 relate to recognition and enforcement of the rule of law, as a basis for the recognition of the constitutional provisions. Article 5 provides for the liberty of a person. Article 6 prohibits slavery and forced labour. Article 7 protects the individual from retrospective criminal laws. Article 8 provides for equality of citizenship. This provision, as we will see, was qualified by a transitional provision (Article 157) which provided for certain special privileges for the Malays in employment in the public service, education scholarships and issuing of permits and licences for trade and businesses. Article 9 protects freedom of movement for the individual in the federation and Article 10 entrenches safeguards for freedom of speech, assembly and association. Article 11 provides for freedom of religion. Article 12 guarantees certain rights in respect of education and Article 13 safeguards rights of property. ${ }^{45}$ The Reid draft on fundamental rights in essence reflected the concerns expressed by Malayan organisations and individuals on basic rights over equality of citizenship, education, religious worship and the use of vernacular languages. The Working Party, comprising representatives of the Alliance government, the Malay rulers and the British government, which reviewed the draft constitution and the London Constitutional Conference made significant changes to the original draft prepared by the Reid Commission. In some instances the changes were motivated by political concerns while in others they were due to changes in drafting style made by the House of Commons' parliamentary draftsmen who assisted the fine tuning of the draft constitution at the constitutional conference in London in May 1957. We examine first the discussions in the Commission revolving around Jennings' drafts.

\section{JENNINGS' WORKING DRAFT}

The first draft prepared by Jennings had ten articles containing the basic fundamental liberties and rights. ${ }^{46}$ These were essentially working drafts which had drawn considerably from similar provisions in the constitutions of India, Pakistan, Eire and Burma, and to a lesser extent from Canada, the United States, South Africa and Ceylon. The provisions in the early drafts were reflective of the libertarian and democratic values of the framers. The commissioners wanted to ensure that safeguards for civil and political liberties were well enshrined in the new constitution, albeit with some 
exceptions on public order grounds as found in most Commonwealth constitutions. The first and second articles of the Jennings' draft provides for the recognition and enforcement of the rule of law. This was a primary constitutional provision found in modern constitutions which provided legitimacy for the provisions in a constitutional document. In themselves, they are not a basic fundamental freedom or right but are important to establish the legality of a constitutional document and enable the legal enforcement of the fundamental rights. The first of these provisions, Article 1 of the draft prepared by Jennings, provided for the federal constitution to be the supreme law of the land and the highest source of authority. Jennings wrote: "This constitution shall be the supreme law of the Federation and any provision of the Constitution of any State or of any written law, and any custom or usage having the force of law, shall, in so far as it is repugnant to any provision of this Constitution, be void." ${ }^{47}$ The article also provided for any act performed by public authority within the Federation or the states which were inconsistent with the federal constitution to be considered void. ${ }^{48}$ Jennings argued in his working paper that this provision on the "rule of law" was necessary to assert the supremacy of the federal constitution over the state constitutions: "This Article is included because (1) the laws of the Malay States have developed out of pure autocracy and relics of that autocracy remain; (2) It is necessary to assert the supremacy of the Federal Constitution over the State Constitutions." ${ }^{49}$ The second article strengthens this element further. Article 2, the enforcement of the rule of law, provides for any person who feels that any provision of the constitution of any State or written law is void, or that any executive act is void, to apply to the Supreme Court to have the provision or act declared void. This article essentially provided for judicial review for the ordinary citizens against public organisations or individuals who acted contrary to the provisions on fundamental liberties. This article, as we will see below, became a bone of contention later as the parliamentary draftsmen felt it was too wide.

Article 3 provides for "liberty of person," and protects the individual from unlawful arrest or detention. The provision, "liberty of the person," Article 3 of Jennings' working draft, enabled the courts to act against unlawful or indiscriminate detention of any person. The initial draft read: "No person shall be deprived of his life or personal liberty save in accordance with the law." ${ }^{50}$ This provision on personal liberty is a basic feature of modern constitutions inspired by the Bill of Rights in the American constitution. This section drew from Article 5(2) of the Pakistan constitution; the Fifth Amendment of the American constitution, Article 21 of the Indian constitution as well as Article 40 (4)(e) of Eire and Article 16 of the Burma constitution. ${ }^{51}$ Jennings preferred Pakistan's Article 5(2) 
compared to the Fifth Amendment in the United States constitution, India's Article 21; Eire 40 (4)(a) and Burma's Article 16.

Article 4 of Jennings' draft provides for the principle of equality of citizens. This article is qualified further by a transitional article, Article 10, which provides for special privileges for the Malays, and some restrictions to the employment of Muslims only in the Muslim Religious Affairs Department. Article 4(1) on equality of citizenship in the federal constitution drew considerably from the 14th Amendment of the American constitution, Article 40(1) of Eire, Article 14 from India and Article 5 from Pakistan. The second part of this article, Clause 4(2), on the other hand, drew from the Government of India Act 1935, Section 298(1), with some adjustments made to accommodate the provision on Malay special position. This article, Jennings noted, had to make provisions for the transitional article relating to special position of the Malays which provided for a certain amount of discrimination against the other ethnic communities and which conflicted with the article on equality. ${ }^{52}$ Thus the fourth provision in Jennings' working draft on "equality of citizens" was intended to provide for equal protection under the law for all citizens regardless of their race, creed or background. Sub-section (1) of this provision reads: "All persons, irrespective of religion, race, sex, language or place of birth shall be equally entitled to the protection of the law." ${ }^{53}$ To emphasise this element further, a second sub-section of this article provides for specific protection in terms of employment, acquiring property and the conduct of business: "No citizen shall, on grounds of only religion, residence, or place of birth, be ineligible for office under any public authority, or be prohibited on any such ground from acquiring, trade, business or profession." There was, however, an exception made for the employment of individuals in religious establishments and thus a third sub-section provides that nothing in the article "shall prevent the restriction to the Muslims of appointments in the Religious Affairs Department of any State." ${ }^{54}$

Article 5 provides for freedom of movement of the citizens in any part of the federation. This article emphasises that no citizen shall be excluded from any part of the country on the grounds only of religion, race, residence, language or place of birth. ${ }^{55}$ Jennings felt that the negative form which he drafted was better than similar provisions in the constitutions of Burma, Article 17(iv), India, Article 19(1) (d) and (e), and Pakistan, Article 10. Religious freedom was constantly raised by numerous organisations and the draft constitution sought to provide adequate protection for this. Article 6 guarantees the freedom of religion with some restrictions based on the requirements of public order, health and morality. Some restriction was placed on the propagation of religion among the aborigines in Malaya. 
Article 6 provided for the freedom to profess, practice and propagate religion subject to, "requirements of public order, public health and morality." ${ }^{56}$ This sub-section also provides constitutional protection for minors in matters of religious practice. In the case of a person under the age of 16, the sub-section provides that the decision as to the religion professed by him shall be taken by his parent or guardian. ${ }^{57}$ For Article 6, Jennings adapted the phrases from similar provisions in Eire (Article 44) and Burma (Article 21) ${ }^{58} \mathrm{He}$ also drew on India (Article 25) and Pakistan (Article 18) for three other clauses in this provision. This section provides for protection for an individual against the need to pay any special taxes for the maintenance or propagation of any religion other than his own. It also provides for wide guarantees for religious groups to manage their own affairs, including maintaining institutions for religious and charitable purposes, and to acquire and manage property. The Jennings' draft, however, did not go as far as the Eire and Burma constitutions which stated explicitly that the state was separate from religion and invariably left a degree of ambiguity in the Malayan context although the Alliance's memorandum had stated clearly that the state was to remain secular. While the constitution of Eire recognises the special position of the Holy Catholic Apostolic and Roman Church ([Article 44(i)(b)]), the constitution states that the state "guarantees not to endow any religion" ([Section 44 (2)(b)]), and shall not impose any disabilities or "discriminate on ground of religious profession, belief or status" ([Section 44 (2)(c) $])^{59}$ In the Burma constitution, while Section 21(1) recognises the special position of Buddhism as the faith professed by the majority of the citizens, sub-section (3) notes that the state shall not impose any disabilities or discriminate on the ground of religion, while sub-section 4 prohibits "the abuse of religion for political purposes." Interestingly, both the Eire and Burma constitutions officially acknowledge the existence of the various other religions at the time of the drafting of their respective constitutions. ${ }^{60}$ Jennings' draft allows Parliament to enact legislation preventing or restricting the propagation of religion among the aborigines, and requires that such restrictions on propagation apply equally to all religions. ${ }^{61}$

Article 7 of Jennings' draft provides for basic rights on education, including the right of the non-Malay communities to establish and maintain schools in the vernacular languages. Every religious organisation is allowed to establish and maintain institutions for education of children. Sub-section one of the article provides that no person may be refused admission to any educational institution on the grounds of religion, race or place of birth, or be refused financial aid or be granted aid under discriminatory conditions. ${ }^{62}$ A third sub-section provides for every religious organisation to have the 
right to establish and maintain institutions for the education of children and to provide religious instruction according to its own faith. Public authorities are prevented from discriminating against such institutions in respect of recognition, taxation or financial aid. ${ }^{63}$ The provisions protect persons from being required to attend religious ceremonies or receive religious instructions in a religion which he does not profess. ${ }^{64}$ Jennings adapted the provisions for Article 7 from the constitutions of India (Article 29(2)) and Pakistan (Article 13(3)). He noted: "This negative form, which accords with the form in Draft Article 4 (2) and with India 29(2) and Pakistan 13(3), is preferred to the 'no discrimination' form of Burma 22. In view of local conditions, it has been thought wise to extend this clause to 'scholarships' and school fees." ${ }^{65}$

Article 8 provides for English and Malay to be used in Parliament while allowing the use of Chinese or Tamil languages if any person requests permission to use these languages in Parliament. ${ }^{66}$ Nevertheless, the article requires that authoritative texts for all Bills, Acts of Parliament and State Enactments, and subsidiary legislation should be in English. Jennings was, however, against the introduction of Malay as an "official language," and did not provide for it in his first draft, pointing to precedents in India and Pakistan which allowed for the continued use of English for a long period. Jennings felt to prescribe a national language would be meaningless at that stage as it would be merely an objective to be achieved. ${ }^{67}$ India, he observed, retained English for 15 years while Pakistan retained English for 20 years. He felt strongly that all legislation should be in English at least for 21 years. After further discussion in the Commission and listening to submissions from the Alliance, the Reid Commission, recognising that this was a political decision, provided for the recognition of Malay as a national language and for the use of English as an official language for 15 years in the final draft. ${ }^{68}$

Article 9 provided for the rights of property and was not controversial as most modern constitutions contain a provision for the protection of private property; a trend that began with the United States' constitution. The Malayan federal constitution was no exception to this trend. Jennings' working draft provided protection of an individual's property and in case of acquisition of property, adequate compensation. The first sub-section of the article prepared by Jennings reads: "No person shall be deprived of his property save in accordance with the law." ${ }^{69}$ There is also a bar on parliament from making any new law which provides for compulsory acquisition of property without adequate compensation. ${ }^{70}$ In the case of Article 10 on the special position of the Malays in Jennings' first draft, this provision, which was eventually to appear as Article 157 in the Reid draft 
and Article 153 in the final constitution, Jennings drew on similar "affirmative provisions" in the constitution of Pakistan (Article 15 (1)); the fifth amendment in the United States constitution; and Section 299(10) of the Government of India Act 1935; and the Indian constitution, Article 31(1). The constitutions in these countries provided for some preferential treatment given to certain groups of people in respect of educational and business opportunities and Jennings adapted these provisions to suit the Malayan situation. ${ }^{71}$

Jennings' draft provisions on fundamental liberties clearly were drawn from the constitutions of Asian Commonwealth countries, mainly India, Pakistan and Burma. The multiethnic nature of the populations of these countries had similarities comparable to Malaya and the framers felt constitutional precedents in these countries suited conditions in Malaya. Jennings thus did not have to reinvent the wheel, but his legal astuteness and knowledge of Commonwealth constitutions (he was involved in the drafting of the Pakistan constitution with Justice Abdul Hamid and in the drafting of the constitutions of Malta, Maldives and Ceylon) enabled him to draw from the best of articles on fundamental liberties based on Common Law, backed by case precedents, and adapt them to the Malayan conditions. ${ }^{72}$ Jennings' draft sought to provide for the basic fundamental rights found in modern democracies, while accommodating some exceptions found in the complex multiethnic Malayan environment.

\section{DISCUSSIONS IN THE REID COMMISSION}

The Reid Commission first discussed Jennings tentative drafts on fundamental liberties containing ten articles on 8 October $1956 .^{73}$ There was considerable agreement among the members on the draft prepared by Jennings but they felt some substantial additions and revisions were needed. The major change was the agreement that the section on fundamental liberties should include articles on freedom of speech and assembly. ${ }^{74}$ This was a surprise omission by Jennings in the first draft considering that most of the constitutions that he referred to contained substantive sections on freedom of speech and assembly. At this meeting, the Commission members felt that in respect of the provision for liberty of the person, it should be stipulated that any detention should not be for more than 24 hours. ${ }^{75}$ The panel agreed, after the hearing given to the Alliance, that matters which were not enforceable in a court of law should not be included. ${ }^{76}$

A more substantive discussion of the section on fundamental liberties was held the next day. ${ }^{77}$ Among the sub-sections discussed, based on 
Jennings' working drafts, were equality of citizenship, freedom of movement, freedom of religion, education, language, rights of property and the special position of the Malays. Article 8 in Jennings' first draft on language was substantively rewritten and the new draft stated unequivocally that Malay shall be the national language while the English language shall be an official language for 15 years. Jennings' original version on language was quite vague and did not indicate clearly the status of Malay and the English language. Jennings' draft merely provided for the use of either the Malay or English language to be used for debate in Parliament or the state legislatures, and for the use of Chinese or Indian languages in the legislatures on request for 10 years. ${ }^{78}$ The Alliance had requested that Malay be made the national language and the English language be retained as an official language for ten years after independence. The Commission's amendment also provided for English to be the language of the High Court for 15 years. $^{79}$

Jennings provided a second draft for the section on fundamental liberties on 19 October 1956 incorporating most of the suggestions made at the first meeting on the subject by the Commission. The second draft was better framed and the wording much tighter and had 13 articles. ${ }^{80}$ This draft included a provision on freedom of speech, assembly and association (Article 8), as agreed at the meeting on the first draft, but the earlier provision on Malay special position was omitted as it was moved to the transitional section of the constitution. ${ }^{81}$ In the discussion that ensued, there were minimal changes made to Jennings' second draft which remained largely unchanged until the Working Party in Kuala Lumpur reviewed the draft constitution. The Commission was preoccupied with other major issues such as citizenship and the division of powers between the federal government and the states and the constitutional documents do not indicate a very extensive discussion on Jennings' second draft.

The main difficulty the Commission faced was in balancing the provisions on equality (Article 8) and providing for affirmative policies under the section on Malay special privileges as this provision conflicted with the principle of equality enshrined in the article. The Commission recognised that this was a political compromise between the Alliance parties to assist the Malays economically and sought to provide for this element as a transitional measure in the constitution. ${ }^{82}$ The discussion of the articles on fundamental liberties did not involve a prolonged debate between the Commission members as they shared a fairly liberal outlook on the rights and liberties that individuals should be entitled to in a political system. The politicians in the review committee, the Working Party, however, had some concerns over the political implications of certain provisions on 
fundamental liberties and this, as we will see below, required further compromises.

\section{THE WORKING PARTY AND LONDON CONFERENCE DISCUSSIONS}

The Working Party in Malaya, comprising the representatives of the Alliance Party and the Rulers, and the High Commissioner and his aides, reviewed the draft constitution submitted by the Reid Commission and made significant changes following discussions between 22 February and 22 May 1957. Almost half of the articles in the section on fundamental rights were accepted without debate. These were the drafts of articles on liberty of the person (Article 5), prohibition on slavery and forced labour (Article 6), protection against retrospective criminal laws (Article 7), freedom of movement in the Federation (Article 9) and rights of property (Article 13). However, the articles on the rule of law (Article 3) and enforcement of law (Article 4), equality (Article 8), freedom of speech, assembly and association (Article 10), freedom of religion (Article 11) and rights in respect of education (Article 12) drew considerable discussion in the Working Party.

UMNO, the senior partner in the Alliance, was concerned that financial assistance to Muslim religious institutions should be safeguarded in the constitution and the previous non-discrimination against aid to any religious institutions (Article 12) by public authorities was considerably toned down by the Working Party, favouring Muslim religious institutions. ${ }^{83}$ The propagation of any religion other than Islam among Malays continued to be restricted as provided in the constitutions of some states. UMNO also requested that Islam be made the religion of the federation while providing for other religions to be practised freely in the federation. ${ }^{84}$ This resulted in the introduction of Article 3 (initially Article 2A in the Working Party draft) making Islam the religion of the federation. ${ }^{85}$ UMNO's partners in the Alliance, the MCA and MIC, on the other hand, were focused on ensuring that the freedom of worship was safeguarded in the constitution and that protection for the rights to education, vis-a-vis the Chinese and Tamil vernacular schools, was enshrined and did not object to these changes.

Article 8 on equality also drew considerable attention. At the first meeting of the Working Party on 22 February 1957, the Rulers' representatives pointed out that the provisions on equality (Article 8) should not invalidate provisions of any state constitution which had elements of ethnic preferential treatment. ${ }^{86}$ They noted that some state constitutions 
provided for the Mentri Besar (Chief Minister) to be a Malay who professed the Muslim faith and who was a subject of the Ruler. The Alliance while taking note of the Rulers' position remained non-committal on the issue initially. A compromise between the Alliance and the Rulers' positions was reached after further discussion. First, a new proviso in the article enabled the Ruler to waive the provision requiring a Malay to be appointed at his discretion $^{87}$ and, second, an additional proviso to Article 8 provided that nothing in the article "shall invalidate any provision contained in any State constitution in force on 1 January 1957." ${ }^{18}$ This political compromise essentially allowed for the Rulers to appoint a Malay to the position of Mentri Besar (Chief Minister) as contained in some state constitutions while at the same time enabled them to waive the proviso to allow the appointment of a non-Malay to the position if circumstances necessitated this.

In respect of Article 11 on freedom of religion, the Rulers' representative suggested that the word, "propagate" in Clause 1 of the Article should be omitted because the Rulers felt that it was not desirable for non-Muslims to proselytise Muslims. The Alliance representatives, however, argued that to remove the word "propagate" would have the effect of preventing the propagation of any religion, including Islam. ${ }^{89}$ As a compromise, both parties agreed to the insertion of a proviso to the clause that in effect would not invalidate any state law relating to Islam or affecting the Malays. ${ }^{90}$ This was to accommodate some state laws which prevented the propagation of any other religion to Malays. ${ }^{91}$ The Rulers' representatives also raised some objection to a clause in Article 11 which enabled federal law to prohibit or restrict the propagation of any religion among the aborigines. ${ }^{92}$ The Reid Commission was concerned over the propagation of religion among the aborigines and felt that any restriction should apply equally to all religions. At the suggestion of the Alliance, it was agreed that this clause should be deleted.

Both the Alliance and the Rulers' representatives agreed to the provisions of Article 13 on rights of property which was not deemed controversial and which was found in most modern constitutions. ${ }^{93}$ There was minimal discussion at the London conference in May 1957 on the section on fundamental liberties of constitution. The conference was preoccupied with the discussion of citizenship and especially the issue of Commonwealth citizenship, aspects of the federation government and appeals to the Privy Council. The United Kingdom parliamentary counsel who assisted the final drafting at the constitutional talks in London nevertheless made some substantive changes to the phrasing style of the wording of several articles in the section. ${ }^{94}$ In many cases the rewording by 
the parliamentary counsel improved the phrasing of the articles. But at times the Malayan delegation was a little overwhelmed by the changes made to the revised draft prepared by the Working Party in the Federation of Malaya and the Alliance leaders reminded the Secretary of State of the importance of keeping to the substance of the drafts agreed in Malaya which they stressed were political compromises. The committee at the conference was told that many aspects of the constitution was the result of extensive discussion and local agreement in Malaya and "it was politically very important to leave the wording unaltered as far as possible."

One of the major changes made to the Reid Commission's draft was the omission of Article 4 which provided for "enforcement of the rule of law," a kind of judicial review against decisions of public authorities, on the advice of the parliamentary counsel. The parliamentary counsel, H. P. Rowe, advised the committee at the London constitutional talks that it would be difficult to compress the lengthy Article 4 into a single article and it would be "unwise to attempt to do so." ${ }^{16}$ The committee agreed that ordinary legislation in the federation provided sufficient safeguards for appeals against public authorities and that the article should be omitted. The White Paper produced by the government explained: "The Article proposed by the Commission on the subject of enforcement of the rule of law was, however, found unsatisfactory and has been omitted on the ground that it is impracticable to provide within the limits of the Constitution for all possible contingencies. It is considered that sufficient remedies can best be provided by the ordinary law." ${ }^{97}$ The parliamentary counsel also advised the omission of the second clause of Article 3 which enabled action to be taken against any public authority whose actions were inconsistent with any provisions of the constitution. These omissions drew the ire of the Commission. Lord Reid and Jennings later expressed much anger at the omission of Article 4 which they felt provided an important safeguard against the excesses of government by enabling citizens to apply for judicial review if they felt that the government or any public authority had exceeded their powers. ${ }^{98}$ Jennings was equally scathing of changes made to Article 4 . He wrote to Reid: "I share your doubt about Article 3 (4) [should read as 4(3)]. Interpreted literally, it clearly deprives the citizens of any remedy for the breach of a right conferred by Part II [Fundamental liberties]. If that is the intention it is a politically most serious matter."99 One of the parliamentary draughtsmen, Noel Hutton, admitted that changes to some of the articles may have created new ambiguities but blamed the defects on the limited time the draftsmen had to revise the drafts. ${ }^{100}$ The Secretary of State subsequently offered an apology to Reid over remarks made in the White Paper. ${ }^{101}$ 


\section{THE INTENT OF THE FRAMERS}

Several guiding principles underlay the provisions on fundamental liberties. One of the main underlying principles was the framers' intent to provide for the growth and development of a democratic way of life based on the norms and values of parliamentary democracy. This is clear from the discussions in the Commission and in its report which emphasised that certain fundamental rights were essential for "a free and democratic way of life."102 The provision for freedom of speech, assembly and association (Article 10) was intended to provide for the growth and development of a vibrant democracy. This is buttressed by the provision on equality of citizenship (Article 8), one of the hallmarks of a working democracy, and freedom of religion (Article 11) which was intended to safeguard freedom of worship for the multireligious population and to provide for the separation of state and religion. The Reid Commission's draft on fundamental rights in this sense was considerably more balanced and holistic then the final draft which emerged after the review by the Working Party in the federation and the committee at the London constitutional talks in 1957.

Several changes made to the articles on equality (Article 8), freedom of speech, assembly and association (Article 10) and freedom of religion (Article 11) eroded considerably the safeguards inbuilt in the Commission's original draft. As a result, the article on equality lost its force in safeguarding against discrimination by the state or public institutions. For instance, the Reid Commission provided for the continuation of Malay special privileges (Article 157) for a temporary period in the transitional section so that the article on equality (Article 8 ) would not be eroded in the long run. The decision of the Working Party to entrench more strongly Malay special privileges by moving it from the transitional section of the constitution to the permanent section and the omission of a written provision for review of the position after 15 years, as agreed in the Alliance, had the effect of weakening the constitutional safeguards for individual rights. Article 10 providing for freedom of speech, assembly and association underlines the intent of the Commission to entrench the basic civil and political liberties that individuals are entitled to in a democracy, in spite of restrictions of public order and morality as the latter restrictions were a norm in modern constitutions. Such restrictions were also found in the Indian and Pakistan constitutions. These were nevertheless positive rights that citizens were empowered with to encourage the growth of a strong democracy.

A second underlying principle of the section on fundamental liberties was the framers' intent to curb the excessive powers of the state and to 
ensure that the basic rights and liberties of the individuals are protected. The Reid draft provided for a range of contingencies in respect of the protection for the individual vis-a-vis the powers of the state and public institutions and a better check and balance through Article 3 and Article 4. Thus not surprisingly when Article 4 was omitted following discussions at the London constitutional talks, Reid and Jennings expressed much disappointment. Reid pointed out that the article was intended to check the excesses of the government in respect of the rights to judicial review if a public authority or the government introduced policies that were deemed discriminatory. ${ }^{103}$ The parliamentary draftsmen admitted that the changes made to Article 3 and Article 4 could have created new weaknesses in the constitution but their recognition of this oversight came a little too late as the constitution had already been finalised. ${ }^{104}$

Protection for basic socio-cultural rights in respect of freedom of worship and rights on education is a third important principle inherent in the section on fundamental liberties. This followed written and oral evidence given by numerous organisations and individuals, including the Alliance Party, of concerns expressed by a cross-section of the population of the importance of safeguarding basic rights in respect of freedom of worship and rights on education. ${ }^{105}$ Many non-Malay organisations in particular expressed considerable concerns for the need to provide adequate safeguards in the constitution for religious freedom, as well as protection for the vernacular languages and for the Chinese and Tamil school systems. ${ }^{106}$ Thus Article 11 (Freedom of worship) and Article 12 (Rights in respect of education) sought to provide adequate safeguards for religious freedom and choice in terms of education. Article 11 provides that every person has the right to profess, practise and propagate his religion, subject to requirements of public order, public health and morality, which was a norm in many Commonwealth constitutions. While the issues of public order, public health and morality were left undefined, giving room for some vagueness, the framers clearly intended this as a positive right and that all religious groups were to be able to worship freely without hindrance. The rights in respect of education were historically a longstanding demand from the Chinese and Indian communities who wanted constitutional safeguards for the Chinese and Tamil school systems. The Commission recognised this demand as a legitimate right of these communities, and in the face of concerns expressed by organisations and individuals representing these communities, felt that these rights should have constitutional safeguards. The provisions on fundamental liberties and rights in the constitution invariably were viewed by the framers as a work in progress. 


\section{CONCLUSION}

The provisions for fundamental liberties in the Malayan constitution are reflective of a concern for the basic political and socio-cultural rights of the citizens. On the eve of independence, many organisations and individuals expressed the need for clear safeguards in the federal constitution for the basic fundamental liberties and rights of the citizens in their memoranda sent to the Commission. These concerns over equality of citizenship, rights in respect of education, freedom of worship, freedom of speech, assembly and association, and over the right to use the vernacular languages after independence influenced considerably the framing of the section on fundamental rights. The Reid Commission thus provided for a fairly elaborate section on fundamental liberties in the constitution, drawing considerably from similar provisions in several Asian Commonwealth constitutions. In doing so, they hoped that this would enable the growth and development of a vibrant democracy. Significant changes were made to the draft constitution prepared by the Commission by the Working Party which reviewed the draft in the federation in February 1957 and by the committee which examined the draft at the London constitutional talks in May 1957. The impact of the changes made by the Working Party and the committee in London is clearly reflected in the sentiments expressed by Lord Reid and Jennings in correspondence between these two legal experts and the Colonial Office, as noted above. While the question of expedience, the rush to prepare the constitution in time for independence in August 1957, ineptness and the lethargy of the parliamentary counsel contributed to some of the defects in the final constitution, the lack of foresight and deep thought among the Alliance leaders on these contentious issues also contributed significantly to the weaknesses in the section on fundamental rights. What was deemed normative provisions in the constitutions of India, Pakistan and Burma in respect of constitutional safeguards for fundamental rights and adopted by the Reid Commission were considerably weakened by the Working Party in Malaya, and the committee and the parliamentary draftsmen at the London constitutional talks. The fundamental liberties and rights essential for a full democratic way of life inserted in the constitution as such was considerably undermined by the numerous changes made to the Reid Commission's draft. 


\section{NOTES}

* Joseph M. Fernando is an Associate Professor in the Department of History, Faculty of Arts and Social Sciences, University of Malaya, Kuala Lumpur, Malaysia. He obtained his $\mathrm{PhD}$ in history from Royal Holloway College, University of London. His main areas of specialisation are Malaysian political and constitutional history. $\mathrm{He}$ also has a broader interest in British colonialism, Southeast Asian history and Commonwealth constitutional history. He teaches courses on Malaysian political history and the modern history of Southeast Asia at the Department of History in the University of Malaya at the undergraduate and postgraduate levels. His publications include The Making of the Malayan Constitution (Kuala Lumpur: Malayan Branch of Royal Asiatic Society, 2002), The Alliance Road to Independence (Kuala Lumpur: University of Malaya Press, 2009) and "British and Commonwealth Legacies in the Framing of the Malayan Constitution, 1956-1957," Britain and the World, Vol. 8, No. 2 (2015).

** Shanthiah Rajagopal graduated with a $\mathrm{PhD}$ in history from the Department of History, University of Malaya in 2015. Her thesis examined the origins and development of the Malayan Indian Congress between 1946 and 1957. Her research interests include Malaysian political history, Malaysian Indian political history and the Indian diaspora in Southeast Asia. She has previously worked as a tutor in the Indian Studies Department, Faculty of Arts and Social Sciences, University of Malaya. She is currently an independent researcher. Her most recent publications include "Pembentukan Indian National Army dan Perjuangannya Semasa Pendudukan Jepun, 1941-45," (The Formation of the Indian National Army and its Struggles During the Japanese Occupation, 1941-45), Sarjana, Vol. 27, No. 1, (June 2012); and "Masyarakat India dan Perjuangannya Selepas Pendudukan Jepun di Tanah Melayu, 1945-1950," (The Indian Community in Malaya and its Struggles after the Japanese Occupation, 1945-1950), Journal Sejarah, Vol. 21 (2013).

1 Mitchell, R., CQ's guide to the U.S. constitution (Washington: Congress Quarterly Incorporated, 1994).

2 Wheare, K. C., Modern constitutions (London: Oxford University Press, 1964).

3 See Wheare (1964), Modern constitutions, 46-74. See also Wheare, K. C., The constitutional structure of the Commonwealth (Oxford: The Clarendon Press, 1960). The Government of India Act 1935 (Section 298), for example, has clear provisions to protect discrimination in employment for public service, safeguards for private property and protection of the legitimate interests of minorities.

4 See Report of the Federation of Malaya Constitutional Commission, 1957 (London: Her Majesty's Stationery Office, 1957), 70-71.

5 The Malayan population in 1955 comprised Malays, 3,000,181 (48.8 percent); Chinese, 2,326,498 (37.8 percent); Indians, 729,013 (11.8 percent); and others, 93,407 (1.5 percent). See Memorandum by Registrar of Malayan Statistics to Reid Commission, B/X/5/I, Jennings Papers, Institute of Commonwealth Studies, University of London, London.

6 Report of the Federation of Malaya Constitutional Commission 1957, 69-70.

7 Hickling, R. H., An introduction to the constitution of Malaysia (Singapore: Malayan Law Journal, 1960); Sheridan, L. A., The Federation of Malaya constitution (Singapore: University of Malaya Law Review, 1961); Hashim, M. S., An 
introduction to the constitution of Malaysia (Kuala Lumpur: Government Printer, 1972); Trindade, F. A. and Lee, H. P. (eds), The constitution of Malaysia: Further perspectives and development (Singapore: Oxford University Press, 1986); and Bari, A. A., Malaysian Constitution: A critical introduction (Kuala Lumpur; The Other Press, 2003). Hickling has also written a chapter entitled, "Some aspects of fundamental liberties under the Constitution of the Federation of Malaya," Essays in Malaysian law, ed. Hickling, R. H. (Kuala Lumpur: Pelanduk Publications, 1991), 127-148. The legal scholar Shad S. Faruqi discusses briefly some legal aspects of the provisions on fundamental liberties in an article entitled, "Fundamental liberties in Malaysia: An overview," in Insaf (September 1985), journal of the Malaysian Bar. Andrew Harding provides a useful legal interpretation of the provision on fundamental liberties but this work does not contain a discussion of the historical process of the framing of these provisions. See Harding, A., Law, government and the constitution in Malaysia (Kuala Lumpur: Malayan Law Journal, 1996), 189-227. See also Andrew Harding's, The Constitution of Malaysia: A contextual analysis, (London: Bloombsbury Publishing, 2012), 36-42; 161-178 and 236-241, which has some useful discussion on the fundamental liberties from a legal perspective, including the post-1957 period, but does not examine the primary constitutional debates. Harding contends that the fundamental liberties were limited in scope. Joseph M. Fernando's The making of the Malayan Constitution (Kuala Lumpur: Malaysian Branch of the Royal Asiatic Society, 2002), provides some discussion on the provisions on fundamental liberties based on primary constitutional documents but does not deal with the subject in depth.

8 See Memorandum by Secretary of State for Colonies, 21 Oct. 1955, CAB 129/78, C.P. (55) 162.

9 See Report of the Federation of Malaya Constitutional Commission Conference, January-February 1956, CAB 129/79, for the details of the agreement reached at the London conference.

10 For background on the Malayan constitutional commission, see file on constitutional commission, CO 1030/136 (7).

11 Ibid.

12 See Report of the Federation of Malaya Constitutional Commission, 3-4.

13 Report of the Federation of Malaya Constitutional Commission, 2.

14 Ibid.

15 Ibid., 70.

16 Ibid.

17 Alliance party memorandum, 27 Sept. 1956, 10, UMNO/SUA 154/56, Arkib Negara Malaysia.

18 See appendix in the Alliance memorandum dated 27 September 1956. This longer list in the appendix listed 14 fundamental rights the Alliance wanted written into the constitution. They were: (a) equality before the law; (b) protection of life and personal liberty; (c) freedom from arrest and detention except according to law; (d) protection against retrospective offences and punishment; (e) freedom of speech, expression, assembly and association; (f) freedom of worship, faith and belief; (g) freedom to acquire, hold and dispose of property; (h) protection against confiscation of property except according to law and with due compensation; 
(i) protection against slavery and forced labour; (j) freedom to engage in trade and in the profession; ( $\mathrm{k}$ ) protection of children in employment of a hazardous nature; (l) freedom to profess, practice and propagate any religion, and to establish and maintain religious institutions; (m) protection of the languages and culture of all races, and of their schools and cultural institutions; and (n) protection of the legitimate interests and rights of minorities. Record of hearing given to the Alliance Party by the Reid Commission, 27 September 1956, CO 889/1 (33), The National Archives (TNA) of Britain.

20 Minutes of Constitutional Commission meetings, See CO 889/1.

21 See Fernando, J. M., The making of the Malayan constitution (Kuala Lumpur: Malayan Branch of Royal Asiatic Society, 2002), 95-142.

22 Summary of record of 34th meeting of Constitutional Commission, 26 September 1956, CO 889/1.

23 Notes of meeting of Constitutional Commission, 5 September 1956, CO 889/8/1. Nine individuals also touched on fundamental rights in their submissions to the Commission.

24 Memorandum by People's Progressive Party, 20 July 1956, CO 889/5 (1), 2.

25 Memorandum by Pan-Malayan Federation of Chinese Associations, 20 July 1956, CO 889//8/6, 4.

26 Memorandum by the Labour Party of Malaya, 25 September 1956, CO 889/3 (5), 4.

27 Memorandum by Straits Chinese British Association, Penang, 14 July 1956, CO $889 / 5$ (1), 6-7.

28 Memorandum by the Eurasian Union of Malaya, 1 Sept. 1956, CO 889/8/7, 15.

29 Memorandum by Malayan Christian Council, 18 July 1956, CO 889/5 (1), 5. It wanted provisions for freedom of speech expression, assembly, to form associations and freedom of movement, among others, written into the constitution.

30 Memorandum by Malayan Sikhs' Representative Committee, 14 July 1956, CO 889/5 (1), 5-6.

31 Memorandum by the Persatuan Melayu Semenanjong (Peninsular Malay Union) based, 15 July 1956, CO889/5 (1)(b).

32 Memorandum by Malaya Tamil Pannai, 28 September 1956, CO 889/6 (1).

33 Hearing of the Alliance Party, 27 September 1956, CO 889/1 (33). The Alliance party was represented by Tunku Abdul Rahman, Dato' Abdul Razak, V. T. Sambanthan, Mohamed Khir Johari, Yong Pung How, Ng Ek Teong, K. Ramanathan and Senu Abdul Rahman.

34 Record of Alliance meeting with the Constitutional Commission, 27 September 1956, CO 889/6.

Ibid.

36 Ibid.

37 Ibid.

38 Ibid.

39 Ibid.

40 Ibid.

41 Ibid.

42 Ibid. 
43 "Fundamental liberties, etc.," by Sir Ivor Jennings, 21 September 1956, CO 889/2, C.C. $2000 / 26$ (2).

44 Ibid.

45 Report of the Federation of Malaya Constitutional Commission, 1-5.

46 See paper entitled, "Fundamental liberties, etc.," by Sir Ivor Jennings, 21 September 1956, CO 889/2, C.C. 2000/26 (2).

47 Ibid.

48 Ibid.

49 Paper on "Fundamental liberties: Comments on drafts," prepared by Jennings, 21 September 1956, CO 889/2, C.C. 2000/26 (2b).

50 See Paper entitled, "Fundamental liberties, etc.," by Sir Ivor Jennings, 21 September 1956 , CO $889 / 2$, C.C. $2000 / 26$ (2). The article provides for the courts to enquire if a complaint is made as to the cause of the detention and unless it is lawful, for the individual to be released.

51 See Jennings, "Fundamental liberties: Comments on drafts," September 1956 in CO 889/2. The second clause in the same article was taken from Eire 40 (4)(b).

52 "Fundamental liberties: Comments on the drafts," 21 September 1956, CO 889/2, C.C. $2000 / 26$ (2b).

53 Paper on "Fundamental liberties" prepared by Jennings, 21 September 1956, CO $889 / 2$, C.C. $2000 / 26$ (2).

54 Ibid.

55 Ibid.

56 Ibid.

57 Ibid.

58 "Fundamental liberties: Comments on the drafts," 21 September 1956, CO 889/2, C.C. $2000 / 26$ (2b).

59 Paper by Jennings entitled, "Fundamental liberties: Quotable precedents," 21 September 1956, CO 889/2, C.C. 2000/26 (2c).

60 Paper by Jennings entitled, "Fundamental liberties: Quotable precedents," 21 September 1956, CO 889/2, C.C. 2000/26 (2c). Article 44(1)(c) of the Eire constitution states: "The State also recognizes the Church of Ireland, the Presbyterian Church in Ireland, the Methodist Church in Ireland, the Religious Society of Friends in Ireland as well as the Jewish congregations and the other religious denominations existing in Ireland as the date of the coming into operation of this constitution." Article 21 (2) of the Burma constitution, on the other hand, notes: "The State also recognizes Islam, Christianity, Hinduism and Animism as some of the religions existing in the Union at the date of the coming into operation of this Constitution."

61 Paper by Jennings, "Fundamental liberties, etc.," 21 September 1956, CO 889/2, C.C. 2000/26 (2c). Sub-section 5 of Article 6 in Jennings' draft states: "Nothing in this section shall forbid the enactment of laws by Parliament for the purpose of prohibiting or restricting the propagation of religion among aborigines, but any such prohibition or restriction shall apply equally to all religions."

62 Paper on "Fundamental liberties" prepared by Jennings, 21 September 1956, CO $889 / 2$.

63 Ibid. 
64 Ibid. The sub-section reads: "No person attending any educational institution shall be required to receive religious instruction, or to take part in any religious ceremony, or to attend religious worship, if such instruction, ceremony or worship relates to a religion which he does not profess."

65 "Fundamental liberties: Comments on the drafts," 21 September 1956, CO 889/2, C.C. 2000/26 (2b). See also Paper by Jennings entitled, "Fundamental liberties, etc.," 21 September 1956, CO 889/2, C.C. 2000/26 (2c). Article 29 (2) states: "No citizen shall be denied admission into any educational institution maintained by the State or receiving aid out of States funds on grounds of only religion, race, caste, language or any of them." Article 13 (3) of the Pakistan constitution states: "No citizen shall be denied admission to any educational institution receiving aid from public revenues on the ground only of race, religion, caste, or place of birth."

66 Paper by Jennings, "Fundamental liberties, etc.," 21 September 1956, CO 889/2, C.C. 2000/26 (2).

67 Paper by Jennings, "Fundamental liberties, etc.: Comments on the Drafts," 21 September 1956, CO 889/2, C.C. 2000/26 (2b). Jennings noted: "To prescribe a 'national language' would be meaningless, except as an objective which could not be attained for a generation. There will be, presumably, no limitation in the Constitution on media of instruction or compulsory languages for educational purposes; and the 'national language' can be brought in there if Parliament so desires. To prescribe Malay as 'official language' would at this stage be ridiculous, because Malay cannot be used for higher or technical education, higher administration, the administration of justice, or the process of legislation. Indeed it is necessary as in India 348 (1) (b), to prescribe that all legislation shall be for the time being in English. The Indian provision is 'until Parliament by law otherwise provides'; but since nationalist members cannot be allowed to play to the gallery (and their ignorant constituents), control is in fact vested in the Government of India, by India 349, for 15 years." "Fundamental liberties, etc.: Second draft," 10 October 1956, CO 889/2, C.C. 2000/26.

69 Paper on "Fundamental liberties" by Jennings, 21 September 1956, CO 889/2.

70 Paper by Jennings, "Fundamental liberties, etc.," 21 September 1956, CO 889/2, C.C. 2000/26 (2). Sub-section two of the article reads: "Neither Parliament or a State legislature shall have power to make any law authorising the compulsory acquisition or requisition of any property unless the law provides for the payment of adequate compensation."

71 "Fundamental liberties: Comments on the drafts," 21 September 1956, CO 889/2, C.C. $2000 / 26$ (2b).

72 See Fernando, J. M., "Sir Ivor Jennings and the Malayan Constitution," Journal of Imperial and Constitutional History, 34, No. 4, (December 2006), 581.

73 Summary record of the 44th meeting of the Constitutional Commission, 8 October 1956, CO 889/1, C.C. 2000/26.

74 Summary record of the 44th meeting, 8 October 1956, CO 889/1.

75 Minutes of 44th meeting of Constitutional Commission, 8 October 1956, CO 889/2.

76 Summary record of the 44th meeting, 8 October 1956, CO 889/1.

77 Summary record of the 45th meeting, 9 October 1956, CO 889/1. 
78 See paper, "Fundamental liberties, etc.," prepared by Jennings, 21 September 1956, CO 889/2, 2000/26. Jennings draft stated; "(1) Either the Malay or English language may be used in the debates of the Houses of Parliament and of the State Legislatures." It also provides for permission to be granted by the presiding officer if any person requests to speak in Chinese or Indian languages.

79 Summary record of 45th meeting of Constitutional Commission, 9 October 1956, CO 889/2, C.C. 1000.

80 Paper by Jennings titled "Fundamental liberties, etc.: Second draft," 19 October 1956, CO 889/2, C.C. 2000/26 (6). The articles in the second draft were: 1 . The rule of law; 2. Enforcement of the rule of law; 3. Liberty of the person; 4. Slavery and forced labour prohibited; 5. Protection against retrospective criminal laws; 6. Equality of citizens; 7. Freedom of movement; 8. Freedom of speech, assembly and association; 9. Freedom of religion; 10. Education; 11. National language; 12. Official languages; 13. Rights of property.

81 Paper by Jennings titled "Fundamental liberties, etc.: Second draft," 19 October 1956, CO 889/2, C.C. 2000/26 (6).

82 Fernando, "Sir Ivor Jennings and the Malayan Constitution," 577-597.

83 Minutes of First Meeting of Working Party, 22 February 1957, CO 941/85.

84 Minutes of First Meeting of Working Party, 22 February 1957, CO 941/85. See also MacGillivray to Secretary of State, 25 February 1957, CO 1030/524(1), and Minutes of Alliance ad-hoc political sub-committee meeting, 2 April 1957, UMNO/SUA 154/56, Arkib Negara Malaysia.

85 MacGillivray to Secretary of State, 25 February 1957, CO 1030/524(1).

86 Minutes of First Meeting of Working Party, 22 February 1957, CO 941/85.

87 Minutes of Eighth Meeting of Working Party, 8 March 1957, CO 941/85. See also 11th Meeting of Working Party, 12 March 1957, CO 941/85.

88 Minutes of 11th Meeting of Working Party, 12 March 1957, CO 941/85.

89 Minutes of First Meeting of Working Party, 22 February 1957, CO 941/85.

90 Ibid.

91 Minutes of Sixth Meeting of Working Party, 4 March 1957, CO 941/85. At a later meeting on 4 March 1957, it was agreed that Clause 4 of Article 11 incorporating the agreement should read: "Nothing in this Article shall invalidate any State law whereby the propagation of religious doctrines or beliefs among persons professing the Muslim religion is restricted or controlled."

92 Minutes of First Meeting of Working Party, 22 February 1957, CO 941/85.

93 Ibid.

94 Summary record of the First Plenary Meeting, 13 May 1957, CO 1030/496. The two parliamentary counsel who assisted the drafting at the constitutional talks in London were N. K. Hutton and H. P. Rowe.

95 Summary record of the Third Plenary Meeting, 17 May 1957, CO 1030/496.

96 Summary record of First Meeting of Working Party, 14 May 1957, CO 1030/496.

97 Draft of White Paper dated 17 June 1957, CO 1030/486 (7).

98 Reid to Lennox-Boyd, 8 July 1957, CO 1030/486 (16). In a letter to the Secretary of State Alan Lennox-Boyd, Reid noted caustically: As regards the substantial changes in the draft Constitution for Malaya, they seem, apart from those of minor importance, to be designed to give more freedom to the Executive and Parliament 
and correspondingly less full guarantee of the fundamental liberties of individuals than we had recommended. Of course, this is a political question on which none of us expected to have the last word. I only hope that this has not gone too far, because I fear that the Malay ministers will now be under more pressure from the extreme Malays than they would have been if they could have said: "The Constitution prevents us from doing what you want," and the Chinese may quite naturally be troublesome if the Government should succumb to such pressure. Jennings to Reid, 6 July 1957, CO 1030/486 (16).

${ }^{100}$ Hutton to Johnston, CO 1030/486 (18), 10 July 1957. Hutton remarked: "It is of course certain that the draftsman of the original draft will find many points at which he prefers the wording of the original to that of the draft in the White Paper. It is also all too probable, bearing in mind the conditions under which this job was done, that the revised draft will be found to be technically defective at certain points - e.g., where it has set out to deal with one difficulty only to run into another. I hope however that these will prove to be rare."

101 Lennox-Boyd to Reid, CO 1030/486 (19), 15 July 1957. Lord Reid thought the defence offered by the Secretary of State was lame and remarked: "As regards the reflection on us in the White Paper I thought your defence very lame. If I exclude malice the only apparent explanation is stupidity coupled with an offensively patronising air." See Extract of Reid's letter to Lennox-Boyd, 1 August 1957, CO 1030/486 (20).

102 Reid Report, 70.

103 Reid to Lennox-Boyd, 8 July 1957, CO 1030/486 (16).

104 Hutton to Johnston, 10 July 1956, CO 1030/486 (18)

105 See, for example, the Alliance memorandum to the Reid commission, 27 September 1956, 18-19, which states: "We are all agreed that Malay should be the national and official language of Malaysia. We are further agreed that this recommendation should not prejudice the Alliance policy of preserving and sustaining other languages in the education system of the country."

106 See, for example, The Pan-Malayan Federation of Chinese Associations' memorandum to the Reid commission, 20 July 1956, and memorandum of the Eurasian Union of Malaya to the Reid Commission, 1 September 1956, CO 889/8. 